\title{
Effects of bioleaching on the chemical, mineralogical and morphological properties of natural and waste-derived alkaline materials
}

\author{
Yi Wai Chiang a,*, Rafael M. Santos ${ }^{b}$, Annick Monballiu ${ }^{c}$, Karel Ghyselbrecht ${ }^{c}$, Johan A. Martens ${ }^{a}$, \\ Maria Laura T. Mattos ${ }^{\mathrm{d}}$, Tom Van Gerven ${ }^{\mathrm{b}}$, Boudewijn Meesschaert ${ }^{\mathrm{a}, \mathrm{c}}$ \\ ${ }^{\text {a }}$ KU Leuven, Department of Microbial and Molecular Systems, Heverlee, Belgium \\ ${ }^{\mathrm{b}} \mathrm{KU}$ Leuven, Department of Chemical Engineering, Heverlee, Belgium \\ ${ }^{\mathrm{c}}$ Katholieke Hogeschool Brugge Oostende, Department of Industrial Sciences \& Technology, Oostende, Belgium \\ d Brazilian Agricultural Research Corporation (Embrapa), Temperate Climate Research Centre, Laboratory of Agricultural and Environmental Microbiology, Pelotas, Brazil
}

\section{A R T I C L E I N F O}

\section{Article history:}

Available online 6 November 2012

\section{Keywords:}

Bioleaching

Mineral processing

Waste processing

Alkaline materials

Nickel

\begin{abstract}
A B S T R A C T
Bioleaching is a potential route for the valorisation of low value natural and waste alkaline materials. It may serve as a pre-treatment stage to mineral carbonation and sorbent synthesis processes by increasing the surface area and altering the mineralogy of the solid material and by generating an alkaline rich (Ca and $\mathrm{Mg}$ ) aqueous stream. It may also aid the extraction of high value metals from these materials (e.g. Ni), transforming them into valuable ore reserves. The bioleaching potential of several bacteria (Bacillus circulans, Bacillus licheniformis, Bacillus mucilaginosus, Sporosarcina ureae) and fungi (Aspergillus niger, Humicola grisea, Penicillium chrysogenum) towards the alteration of chemical, mineralogical and morphological properties of pure alkaline materials (wollastonite and olivine) and alkaline waste residues (AOD and BOF steel slags, and MSWI boiler fly ash) at natural pH (neutral to basic) was assessed. Bioleaching was conducted using one-step and two-step methodologies. Increased solubilisation of alkaline earth metals and nickel were verified. Alteration in basicity was accompanied by alteration of mineralogy. AOD slag experienced solubilisation-precipitation mechanism, as evidenced by the decline of primary phases (such as dicalcium-silicate, bredigite and periclase) and the augmentation of secondary phases (e.g. merwinite and calcite). Nickel-bearing minerals of olivine (clinochlore, lizardite, nimite and willemseite) significantly diminished in quantity after bioleaching. Altered mineralogy resulted in morphological changes of the solid materials and, in particular, in increased specific surface areas. The bioleaching effect can be attributed to the production of organic acids (principally gluconic acid) and exopolysaccharides (EPSs) by the microorganisms. The similarities between fungal and bacterial mediated bioleaching suggest that biogenic substances contribute mostly to its effects, as opposed to bioaccumulation or other direct action of living cells.
\end{abstract}

(c) 2012 Elsevier Ltd. All rights reserved.

\section{Introduction}

The depletion of high grade natural minerals leads to the search for alternative resources for the mineral processing industry. Additionally, the costly treatment and disposal of waste materials is driving the industry to develop sustainable solutions. Alkaline bioleaching rises as a potential valorisation route for the low-value or hazardous waste materials that consist mainly of calcium and magnesium silicates (Willscher and Bosecker, 2003; Chandraprabha and Natarajan, 2010). Bioleaching may serve as a pre-treatment stage to mineral carbonation (Power et al., 2010) and sorbent synthesis processes. It is envisioned that through the extraction and re-precipitation of alkaline components (e.g. Ca,

\footnotetext{
* Corresponding author. Tel.: +32 494916783.

E-mail addresses: YiWai.Chiang@biw.kuleuven.be (Y.W. Chiang), Boudewijn. Meesschaert@biw.kuleuven.be (B. Meesschaert).
}

$\mathrm{Mg}, \mathrm{Si}$ ), bioleaching can increase material porosity and alter the mineralogy. This effect may enhance the mineral carbonation reactions by overcoming inherent rate and conversion limitations (Santos and Van Gerven, 2011). Moreover, the increased porosity of biodegraded solids, which can result in the formation of microand meso-porous structures, and the re-precipitation of altered crystalline phases onto the solid surface, can also inherently increase the sorption capacity of certain materials, thus enabling their valorisation as sorbents (Chiang et al., 2012). Extracted components from bioleaching processes can be recuperated or utilised for the synthesis of new materials. Solubilised calcium, magnesium and silicon are precursors to many inorganic compounds, including sorbents (e.g. zeolites, hydroxylapatite, and layered double hydroxides (Kuwahara et al., 2010)) and carbon sinks (e.g. precipitated calcium carbonate (PCC)). Bioleaching is also an attractive route for extraction of valuable metals (e.g. copper, nickel) from low grade ores (e.g. ultramafic rocks), given the relatively low 
energy requirements compared to traditional hydrometallurgical processes (namely high-pressure acid leaching (HPAL)).

Microorganisms capable of resisting alkaline environments, including several types of bacteria and fungi, produce organic acids and exopolysaccharides (EPSs) that accelerate the dissolution of siliceous materials (Vandevivere et al., 1994). Acidolysis has been suggested as the principal mechanism in bioleaching with Aspergillus niger (Mulligan and Kamali, 2003), while production of EPS has been attributed to the performance of Bacillus mucilaginosus (Welch et al., 1999). Application of bioleaching in industrial processes is analogous to the acceleration of naturally occurring biodegradation and biodeterioration, which are attributable to mechanical and aesthetic wearing of stony and cementitious construction materials (Warscheid and Braams, 2000; De Belie, 2010; Wiktor et al., 2011). Bioleaching can lead to the extraction of valuable components from raw materials (Groudeva et al., 2007), and the extraction of hazardous components present in waste materials, which reduces the toxicity enabling reutilisation or valorisation (Wu and Ting, 2006; Yang et al., 2010). It can also change the mineralogy of the material, thus altering its reactivity and crystallinity/amorphicity (De Windt and Devillers, 2010). Biodegradation can also increase the surface area and porosity of the material (Wang et al., 2011), and produce (nano)particles (Kulkarni et al., 2008).

The alkaline bioleaching potential of the following microorganisms has been reported in literature: A. niger (Wu and Ting, 2006; De Windt and Devillers, 2010; Ball and Banik, 2011), Humicola grisea (Kulkarni et al., 2008), Penicillium chrysogenum (Groudeva et al., 2007), Bacillus circulans (Vrvić et al., 1990; Ball et al., 2010), Bacillus licheniformis (Mohanty et al., 1990), B. mucilaginosus (Liu et al., 2006; Yang et al., 2010), and Sporosarcina ureae (Chandraprabha and Natarajan, 2010). These studies concerned the bioleaching of the following alkaline materials: oil shale (Vrvić et al., 1990), chromite ore (Ball et al., 2010; Ball and Banik, 2011), magnesite ore (Mohanty et al., 1990), municipal solid waste incineration fly ash (Wu and Ting, 2006; Yang et al., 2010), Portland cement (De Windt and Devillers, 2010), borosilicate glass (Kulkarni et al., 2008), richin-carbonates copper ore (Groudeva et al., 2007), mica and feldspar (Liu et al., 2006).

The aforementioned microorganisms have been reported in the cited literature to survive in alkaline $\mathrm{pH}$, in some cases in the presence of potentially harmful substances contained in waste materials, and to leach silica from siliceous minerals. The published literature also suggests that other desired effects of alkaline bioleaching are possible, such as mineralogical and morphological changes; however the data are insufficient to provide clear direction for implementation, due to the diversity of microorganisms and materials tested and to varying degrees of investigation depth and rigour.

The main objective of this research is to assess the technical feasibility of the desired effects of alkaline bioleaching. The work focused on screening of the seven aforementioned microbial organisms towards their susceptibility of leaching and/or altering five waste-derived and naturally available alkaline materials: Basic Oxygen Furnace (BOF) steel slag, Argon Oxygen Decarburization (AOD) stainless steel slag, municipal solid waste incinerator boiler fly ash (BFA), wollastonite $\left(\mathrm{CaSiO}_{3}\right)$ and olivine $\left((\mathrm{Mg}, \mathrm{Fe})_{2} \mathrm{SiO}_{4}\right)$. The following activities were performed:

- Demonstrate the technical feasibly of alkaline bioleaching to achieve the desired effects: solubilisation of material components, mineral alterations and morphological transformations.

- Determine the most suitable microorganism(s) and material(s) towards producing the desired effects, in view of applying alkaline bioleaching as a pre-treatment stage to mineral carbonation, sorbent synthesis and/or metal extraction processes.
- Elucidate dominant mechanisms of alkaline bioleaching (e.g. leaching and adsorptive actions of organic acids and extracellular polysaccharides (EPSs) and bioaccumulation).

\section{Materials and methods}

\subsection{Microbial strains, growth media and bioleaching materials}

Three fungal and four bacterial strains were obtained from culture collections. The fungal strains utilised were: A. niger (DSM872), P. chrysogenum (DSM-848), and H. grisea (DSM-2691), all obtained from the Deutsche Sammlung von Mikroorganismen und Zellkulturen GmbH (DSMZ, Germany). The bacterial strains utilised were: B. circulans (DSM-11), B. licheniformis (DSM-13), B. mucilaginosus, and S. ureae (DSM-2281). The B. mucilaginosus was obtained from the China Center of Industrial Culture Collection (CICC, China), while the other strains were acquired from DSMZ. S. ureae was maintained on nutrient agar (NAU) $(0.5 \%$ peptone, $0.3 \%$ meat extract, $1.5 \%$ agar) with $0.001 \% \mathrm{MnSO}_{4} \cdot \mathrm{H}_{2} \mathrm{O}$ and $2 \%$ urea. $A$. niger, $P$. chrysogenum and $H$. grisea were maintained on potato dextrose agar (PDA) (infusion from potatoes, $2 \%$ glucose and $1.5 \%$ agar). The Bacillus species were maintained on nutrient agar (NA) with $0.001 \% \mathrm{MnSO}_{4} \cdot \mathrm{H}_{2} \mathrm{O}$ for sporulation enhancement. Growth media components were obtained from Sigma Aldrich (Belgium). All strains were incubated at $30^{\circ} \mathrm{C}$ (bacterial strains for $24 \mathrm{~h}$, fungal strain for 5 days) and preserved at $4{ }^{\circ} \mathrm{C}$. Stock cultures were frozen in $10 \%$ glycerol by quick-freezing with solid $\mathrm{CO}_{2} /$ ethanol and were preserved at $-34^{\circ} \mathrm{C}$.

Wollastonite material (Casiflux F125) was acquired from Ankerpoort (Belgium). Olivine material (GL40) was acquired from N.Z.M. GRIT N.V. (Belgium). Representative samples of boron-free Argon Oxygen Decarburization (AOD) slag, Basic Oxygen Furnace (BOF) slag, and Municipal Solid Waste Incineration Boiler Fly Ash (MSWI, BFA) were obtained from Belgian industries.

\subsection{Bioleaching procedures}

All growth media, solid samples and glass materials were sterilized for $15 \mathrm{~min}$ at $120^{\circ} \mathrm{C}$ prior to use, and every handling was performed under sterile conditions.

\subsubsection{One-step bioleaching}

Inoculation solutions were prepared by inoculating sterile physiological solution using a $5 \mathrm{~mm}$ inoculation loop and diluting them serially to prepare $10^{-1}-10^{-5}$ solutions. One millilitre of the dilution that yielded 30-300 colony forming units (CFUs) upon spread plating was used for inoculation of the 'bioleaching solution'. This solution consisted of $100 \mathrm{ml}$ of the respective nutrient broth of the microbial strain (same composition as nutrient agar, with exception of agar) with $10 \mathrm{~g}$ of solid material placed in $0.25 \mathrm{~L}$ Erlenmeyer flasks. These flasks were shaken at $150 \mathrm{rpm}$ on an incubated shaking table at $30^{\circ} \mathrm{C}$ for 2 weeks. Control experiments were performed in the same way without microbial inoculation. At the end of the bioleaching period, the solids were collected from the aqueous phase by centrifuging (Jouan C412, $3000 \mathrm{rpm}$ for $20 \mathrm{~min}$ ) and overnight drying at $105^{\circ} \mathrm{C}$.

\subsubsection{Two-step bioleaching}

The microbial strains were inoculated into and cultivated in $500 \mathrm{ml}$ of their respective nutrient broths by magnetically stirring in $1 \mathrm{~L}$ Erlenmeyer flasks at $30^{\circ} \mathrm{C}$ in an incubation chamber. After incubation for 7 days, cells were harvested by centrifuging (3000 rpm for $20 \mathrm{~min}$ ) and the total biomass was resuspended in the 'bioleaching solution'. This solution consisted of sterile $500 \mathrm{~mL}$ nutrient broth and $50 \mathrm{~g}$ of solid material in $1 \mathrm{~L}$ Erlenmeyer flasks. Control experiments were performed in the same way 
without adding microbial biomass. The bioleaching reaction was carried out at $30^{\circ} \mathrm{C}$ and flasks were continuously stirred on a magnetic stirrer for a period of 4 weeks. At the end of the bioleaching period, the solids were collected from the aqueous phase by centrifuging and overnight drying at $105^{\circ} \mathrm{C}$.

\subsection{Sampling and analytical methods}

Samples were taken weekly from the bioleached suspensions and relevant parameters including $\mathrm{pH}$, cell counts and elemental concentrations were determined. The $\mathrm{pH}$ was analysed with a $\mathrm{pH}$ metre from Mettler Toledo. Biomass concentration was determined with the spread plate method using a Drigalski spatula and by counting CFU. Samples of $100 \mathrm{~mL}$ were taken and replaced by fresh nutrient broth. Before analytical analysis, aqueous samples were centrifuged for $15 \mathrm{~min}$ at $15,000 \mathrm{~g}$ (Biofuge Stratos) and filtered through a Whatmann paper filter.

Aqueous magnesium and calcium concentrations were measured with a DIONEX DX-100 ion chromatograph (IC) supplied with an IonPac CS12A $4 \times 250 \mathrm{~mm}$ column and conductivity detector with $20 \mathrm{mM} \mathrm{CH}_{3} \mathrm{SO}_{2} \mathrm{OH}$ (methane sulfonic acid) as eluent; the column was supported by an IonPac CG12A $4 \times 50 \mathrm{~mm}$ Guard column and CSRS $3004 \mathrm{~mm}$ suppressor. Aqueous silicon and nickel concentrations were measured by Inductively Coupled Plasma Mass Spectrometry (ICP-MS) (Thermo Electron X Series) in $2 \%$ $\mathrm{HNO}_{3}$ (nitric acid) solutions. Detection of organic acids was performed by high-performance liquid chromatography (HPLC, Agilent Technologies 1200 series).

The chemical composition of solid materials was determined by quantitative X-ray Fluorescence (XRF, Panalytical PW2400). The mineral composition was determined by X-ray Diffraction (XRD, Philips PW1830) equipped with a graphite monochromator and a gas proportional detector, using $\mathrm{Cu} \mathrm{K} \alpha$ radiation at $30 \mathrm{~mA}$ and $45 \mathrm{kV}$, step size of $0.02^{\circ} 2 \theta$ and counting time $2 \mathrm{~s}$ per step, over $5-70^{\circ} 2 \theta$ range. Mineral identification was done in DiffracPlus EVA (Bruker) software and quantitative phase analysis was performed by the full profile Rietveld method implemented in Topas Academic v4.1 software. Specific surface area $\left(S_{\mathrm{BET}}\right)$ was measured by nitrogen adsorption (Micromeritics TriStar 3000) using the BET (Brunauer-Emmett-Teller) model. Loss on ignition (LOI) was measured by thermogravimetric analysis (TGA, TA Instruments Q500). Fourier transform-infrared (FTIR) spectra were recorded on a Perkin Elmer Frontier spectrometer with attenuated total reflection (ATR) accessory in the region of $4000-650 \mathrm{~cm}^{-1}$ at a resolution of $1 \mathrm{~cm}^{-1}$.

\section{Results and discussion}

\subsection{Materials characterisation}

The elemental composition of the five alkaline materials used in bioleaching experiments is shown in Table 1. Four of the materials are predominantly calcium based, with the exception of olivine which is rich in magnesium. AOD slag, wollastonite and olivine contain large amounts of silicon. BOF slag contains substantial amounts of $\mathrm{Ca}$ and $\mathrm{Fe}$, due to its predominant free lime and calcium ferrite composition. Municipal solid waste incineration boiler fly ash has the most distinct composition, containing significant quantities of $\mathrm{Cl}, \mathrm{K}$ and $\mathrm{S}$, indicating high content of salts. In terms of metals and heavy metals, the waste-derived materials contain more varied contents than the pure materials. Most prominent are the $\mathrm{Cr}$ contents of the slags, and the $\mathrm{Pb}$ and $\mathrm{Zn}$ content of BFA. Wollastonite is nearly absent of heavy metals, while olivine contains notable quantities of chromium and nickel. Heavy metal and salt content could be potentially detrimental to the microorganisms due to their toxicity.

The morphology of the solid material particles under SEM imagining is shown in Fig. 1. Of these materials, BFA and AOD slag are used in the experiment as received since they are powdery materials. BFA has considerably finer particles than AOD slag (note image magnifications and scales). BOF slag is produced as a monolith material; therefore the sample utilised for bioleaching was crushed and sieved to $<1 \mathrm{~mm}$ particle size. Similarly, the natural minerals are milled materials, with nominal particle sizes of $57 \mu \mathrm{m}$ and $200 \mu \mathrm{m}$ for wollastonite and olivine, respectively.

\subsection{Microbial screening}

The selected microorganisms (pictured in Fig. 2) were first tested for their bioleaching potential by performing a series of one-step bioleaching experiments. A total of 24 experiments were performed, combining six microorganisms (B. mucilaginosus was unavailable at this stage) with the five alkaline materials of interest. The objective of this research phase was to determine the two most promising microorganisms and materials towards alkaline bioleaching, which would be studied in more detail in the subsequent research phase. The selection criteria are $\mathrm{pH}$ and solubilisation performance ratios, determined by dividing the number of experiments achieving substantial positive results towards alteration of $\mathrm{pH}$, and increased $\mathrm{Ca}$ or $\mathrm{Mg}$ solubilisation, over the total number of experiments performed with each material.

Table 1

Elemental composition (wt\%) of bioleached solid materials determined by XRF.

\begin{tabular}{|c|c|c|c|c|c|}
\hline Element & AOD slag & BOF slag & MSWI, BFA & Wollastonite & Olivine \\
\hline $\mathrm{Al}$ & 0.5 & 1.0 & 2.8 & 0.4 & 0.6 \\
\hline $\mathrm{Ca}$ & 40.6 & 38.5 & 21.4 & 36.6 & - \\
\hline $\mathrm{Cl}$ & 0.02 & 0.03 & 10.4 & 0.02 & 0.06 \\
\hline $\mathrm{Cr}$ & 0.5 & 0.2 & 0.1 & 0.01 & 0.4 \\
\hline $\mathrm{Fe}$ & 0.2 & 23.1 & 1.0 & 0.4 & 6.6 \\
\hline K & - & - & 4.9 & 0.1 & 0.04 \\
\hline $\mathrm{Mg}$ & 4.5 & 0.6 & 1.1 & 0.4 & 27.0 \\
\hline Mn & 0.3 & 3.1 & 0.08 & 0.03 & 0.09 \\
\hline $\mathrm{Ni}$ & - & - & 0.01 & - & 0.4 \\
\hline $\mathrm{Pb}$ & - & - & 0.2 & - & - \\
\hline $\mathrm{S}$ & 0.2 & 0.06 & 9.8 & 0.02 & - \\
\hline $\mathrm{Si}$ & 15.2 & 5.6 & 4.0 & 21.7 & 20.3 \\
\hline $\mathrm{Ti}$ & 0.2 & 0.4 & 1.2 & 0.03 & 0.01 \\
\hline $\mathrm{Zn}$ & - & - & 1.0 & - & - \\
\hline Balance (H,C,O,trace) & 37.8 & 27.4 & 42.0 & 40.3 & 44.5 \\
\hline
\end{tabular}



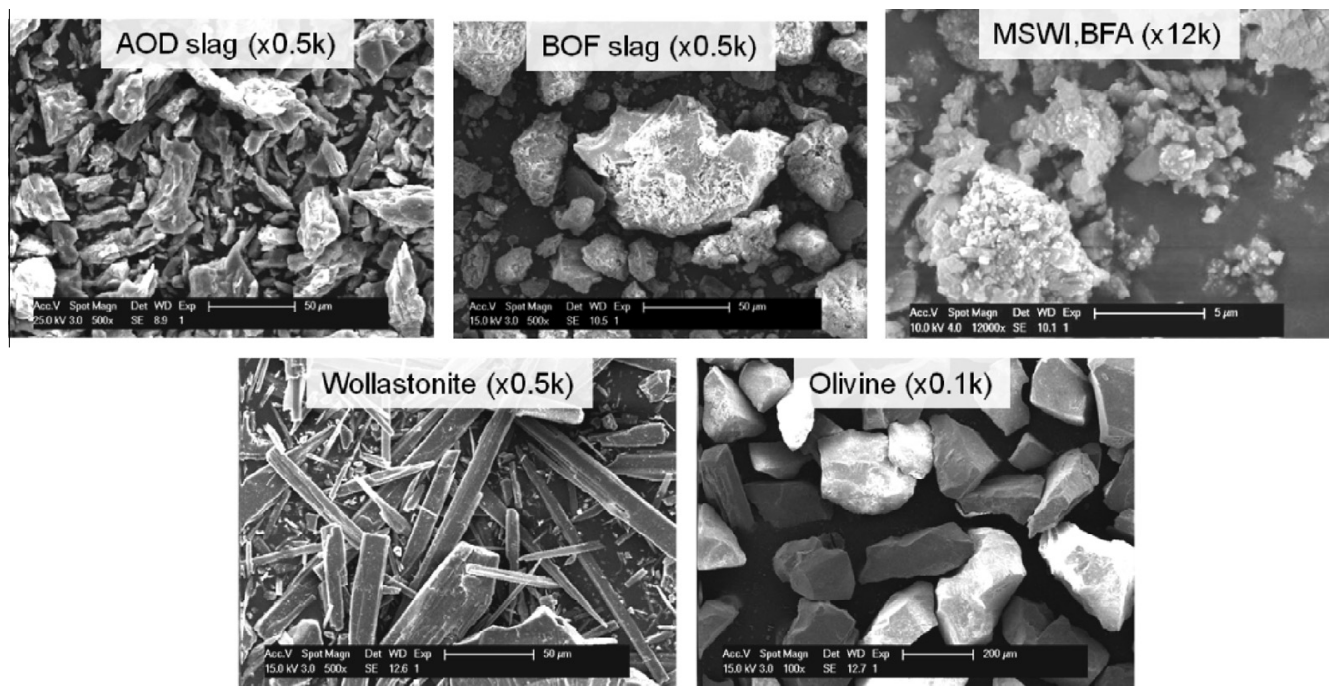

Fig. 1. Morphology of fresh solid materials utilised for bioleaching inspected by SEM.

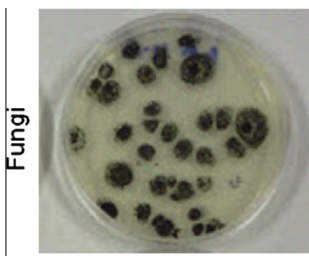

Aspergillus niger

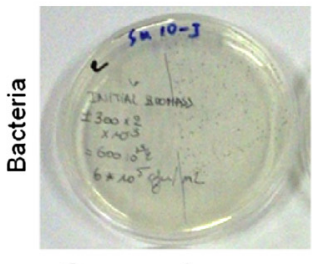

Sporosarcina ureae

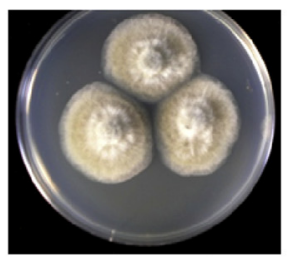

Humicola grisea

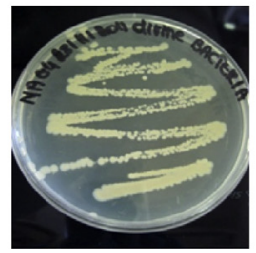

Bacillus circulans

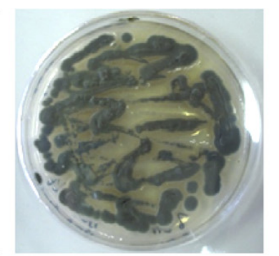

Penicillium chrysogenum
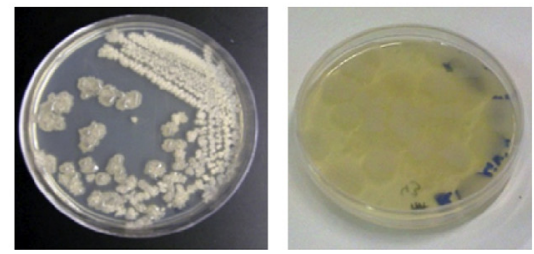

Bacillus licheniformis Bacillus mucilaginosus

Fig. 2. Microbial organism utilised for bioleaching on agar plate.

Solution $\mathrm{pH}$, and solubilisation of calcium and magnesium were monitored during the tests and the bioleaching performance towards each solid material is summarised in Table 2. Values shown are the selection criteria ratios, and the last column is the sum of the two ratios, which is used as a qualitative indication of which solid materials are most susceptible towards alkaline bioleaching, and therefore to be studied in more detail.

AOD slag and olivine achieve the highest marks in their respective categories (waste and natural materials). The $\mathrm{pH}$ of AOD slag consistently increased during bioleaching, possible indicating the degradation of silicate minerals towards their more alkaline

\section{Table 2}

Bioleaching performance and decision matrix for alkaline materials; values equal to ratio of positive tests over total number of tests.

\begin{tabular}{lllll}
\hline Materials & Type & $\mathrm{pH}$ & Solubilisation & Sum $^{\mathrm{a}}$ \\
\hline Olivine & Natural & 1 & 0 & 1.0 \\
Wollastonite & Natural & 0.5 & 0 & 0.5 \\
AOD & Waste & 0.8 & 1 & 1.8 \\
BOF & Waste & 0 & 0.5 & 0.5 \\
Fly ash & Waste & 0.25 & 0.25 & 0.5
\end{tabular}

a Sum of scores in solubilisation and $\mathrm{pH}$ criterion. oxides. Similarly consistent increases in solubilised calcium were observed. With respect to the other two waste materials, it is thought that the soluble salt and heavy metal contents of BFA are detrimental towards the microorganisms and bioleaching performance could be compromised. In the case of BOF slag, its high basicity (12.7, significantly higher than that of the other materials which ranged from 7.8 to 10.8 ) due to large free lime content, and its predominant ferrite mineral content, appear to be inhibitory to satisfactory bioleaching performance. In the case of natural minerals, neither wollastonite nor olivine showed increased solubilisation after bioleaching, however $\mathrm{pH}$ alteration was consistent and significant for olivine. Moreover this material offers greater potential of valorisation due to its valuable metals contents ( $\mathrm{Cr}$ and $\mathrm{Ni}$ ); therefore olivine was chosen for further study.

The average performance of each microorganism towards bioleaching was analysed in similar fashion from the 24 one-step experiments performed, and is presented in Table 3 . In contrast to the materials selection, the average performance of the microorganisms was difficult to differentiate from the ratio summations. Only B. licheniformis performed more poorly than the others. Out of the three fungi tested, $A$. niger was chosen for continuation in the subsequent research phase as its $\mathrm{pH}$ alteration and increased solubilisation performance were more balanced (inferring greater 
Table 3

Bioleaching performance and decision matrix for microorganisms; values equal to ratio of positive tests over total number of tests.

\begin{tabular}{lllll}
\hline Microorganism & Type & $\mathrm{pH}$ & Solubilisation & Sum $^{\mathrm{a}}$ \\
\hline Bacillus circulans & Bacteria & 0.3 & 0.7 & 1.0 \\
Bacillus licheniformis & Bacteria & 0.6 & 0.2 & 0.8 \\
Sporosarcina ureae & Bacteria & 0.7 & 0.3 & 1.0 \\
Aspergillus niger & Fungus & 0.6 & 0.4 & 1.0 \\
Humicola grisea & Fungus & 0.3 & 0.7 & 1.0 \\
Penicillium chrysogenum & Fungus & 0.7 & 0.3 & 1.0
\end{tabular}

a Sum of scores in solubilisation and $\mathrm{pH}$ criterion.

potential for mineralogical alteration), and this microorganism has been more often studied in literature towards bioleaching (both alkaline and acidic) than the other two fungi. With respect to the two satisfactorily performing bacteria, $S$. ureae was chosen for further study as in the next experimental phase another bacillus, $B$. mucilaginosus, was also used (in this way avoiding the use of two bacteria from the same genus, which may work on similar bioleaching mechanisms). By no means does it mean the four omitted microorganism are unsuitable for alkaline bioleaching; further work with them in the future may be valuable.

\subsection{Two-step bioleaching}

Two-step bioleaching experiments were performed with the chosen microorganisms (A. niger (AN), B. mucilaginosus (BM) and $S$. ureae $(\mathrm{SU})$ ) on the selected alkaline materials (AOD slag and

(a)
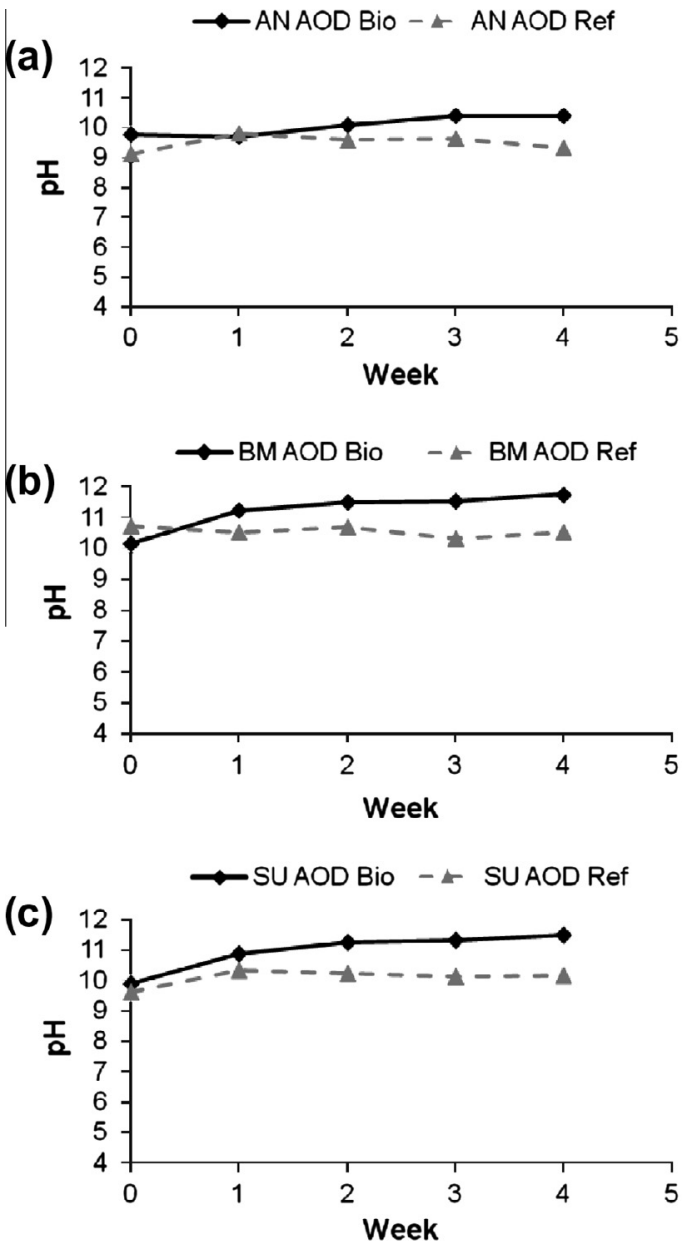

olivine). Two-step bioleaching methodology was selected over one-step bioleaching to ensure the microorganisms had reached substantial levels of growth and generation of extra-cellular biogenic substances (e.g. organic acids and exopolysaccharides (EPSs)) prior to introduction of the solid materials. Yang et al. (2008) found two-step bioleaching more favourable than one-step bioleaching for the extraction of heavy metals from MSWI fly ash at high solids loading ( $>20 \mathrm{~g} / \mathrm{L}$ ), due to the generation of greater amounts of biogenic substances prior to solids addition.

\subsubsection{Solution analysis}

Fig. 3 shows the evolution of the $\mathrm{pH}$ of bioleaching and reference solutions over time ( 4 weeks). The $\mathrm{pH}$ of AOD slag solution was generally higher than olivine throughout due to its higher basicity. AOD slag pH increased during bioleaching by up to 1.5 units, suggesting mineralogical changes; $\mathrm{pH}$ of reference samples was approximately constant for the same duration. The $\mathrm{pH}$ of olivine solutions differed in the first 2 weeks, both for the comparison of bioleaching/reference samples and the different microbial solutions. While bioleaching $\mathrm{pH}$ increased over the first two weeks for all microorganisms, the $\mathrm{pH}$ of reference samples lingered lower until week three. Over time olivine $\mathrm{pH}$ tended to stabilize regardless of sample towards a pH value of approximately 9. This suggests that solubilisation of some alkaline components of olivine is slow, and is intensified by bioleaching. It is also worth noting that the AN + olivine solution (Fig. 3d) had significantly lower $\mathrm{pH}$ compared to other solutions. This is likely a consequence of larger amounts of organic acids produced by the fungus compared to the
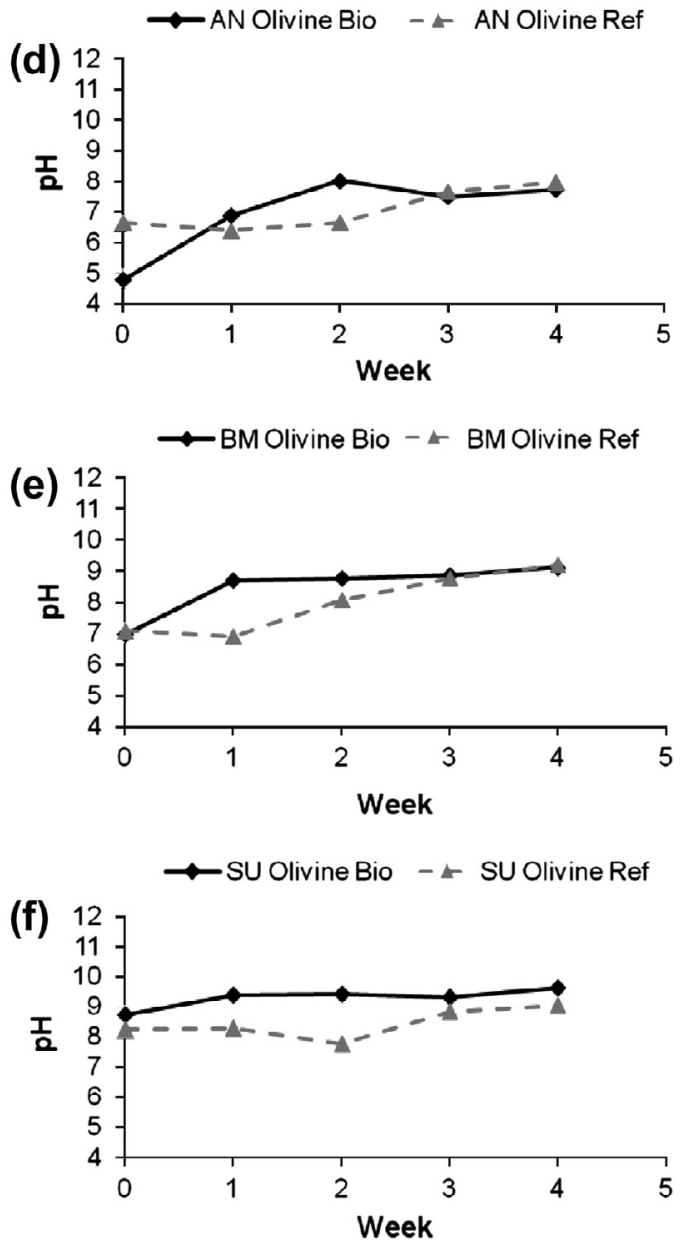

Fig. 3. Solution pH from reference and bioleached (by AN, BM, and SU) AOD slag and olivine over time. 
bacteria. It was verified by HPLC that AN produces significant quantities of gluconic acid; this is in accordance with findings of Wu and Ting (2006), Yang et al. (2008), and Amiri et al. (2011), who found gluconic acid to be the main lixiviant of $A$. niger. The same trend is not seen with AOD slag (Fig. 3a) since it has much higher acid neutralization capacity near its natural $\mathrm{pH}$ value than olivine.

Fig. 4 shows the solubilisation over time of calcium (for AOD slag) and magnesium (for olivine) from bioleached and reference materials. AN achieves the highest levels of solubilisation for both materials, with $\mathrm{Ca}$ amounts one order of magnitude higher than Mg. Reference sample solubilisation in PDA is also higher than for other samples, likely due to its lower $\mathrm{pH}$ (about one unit, see Fig. 3); however, bioleaching increases solubilisation over 4 weeks by about four times. BM and SU do not increase solubilisation of AOD slag compared to the reference sample (Fig. 4b and c), despite the $\mathrm{pH}$ effect previously mentioned. It is possible that the altered minerals produced have lower solubility than the original minerals (e.g. calcite and portlandite). It was also verified by HPLC that organic acid production from the bacteria is low (compared to AN); organic acid is a likely carrier of solubilised $\mathrm{Ca}$ and its presence in AN solutions may be inferred from lower $\mathrm{pH}$ (by approximately one unit) of these solutions (Fig. 3), in addition to verification by HPLC. In the case of olivine, on the other hand, there is evidence of increased solubilisation of Mg by BM and SU (Fig. 4e and f), possibly as a result of greater solubility of altered minerals or greater production of organic acids by the bacteria in the olivine's less alkaline environment. Relatively small quantities of acetic, butyric, citric, formic and lactic acids could be identified by HPLC from bacterial solutions obtained at near neutral $\mathrm{pH}$; these acids have been observed by De Windt and Devillers (2010) to contribute to biogenic degradation of Portland cement. An observation to make is that the $\mathrm{pH}$ of bioleached and reference olivine was the same after 4 weeks (Fig. 3); therefore the amount of extra Mg solubilised by bioleaching may not be 'free' in the solution (which could imply a higher solution $\mathrm{pH}$ ), but adsorbed onto soluble biogenic compounds (and thus not affecting $\mathrm{pH}$ ).

Silicon solubilisation behaves different than the alkaline earth metals (Fig. 5), in particular for the case of AOD slag. The concentrations of Si are lower in the bioleaching solution than in the reference solutions (where silica concentrations are near the predicted equilibrium of $\mathrm{Si}(\mathrm{OH})_{4}$ of $100 \mathrm{ppm} \mathrm{SiO}_{2}$ (Burkin, 2001)). Mechanistically this may be explained by the bioaccumulation of $\mathrm{Si}$, either in the cellular walls or in the produced EPS. These insoluble materials would result in lowering of Si concentration in the analysed (centrifuged) solutions. Bansal et al. (2007) suggested that fungal enzymes may specifically hydrolyse the silicates present to form silicic acid, which on condensation by certain other fungal enzymes results in the synthesis of silica nanoparticles. The effect of bioleaching on Si solubilisation from olivine is opposite, with moderately higher concentrations in the bioleached solutions. The greater contribution of organic acids to Si leaching, produced in larger quantities at moderate $\mathrm{pH}$ (as was previously suggested to explain $\mathrm{Mg}$ solubilisation), may explain this behaviour. This could also explain the slightly higher Si concentrations in the case of AN solutions (Fig. 5a and Fig. 5d), compared to BM and SU. The solubilisation of $\mathrm{Mg}$, however, is significantly higher than that of Si, when it is expected that these two components of
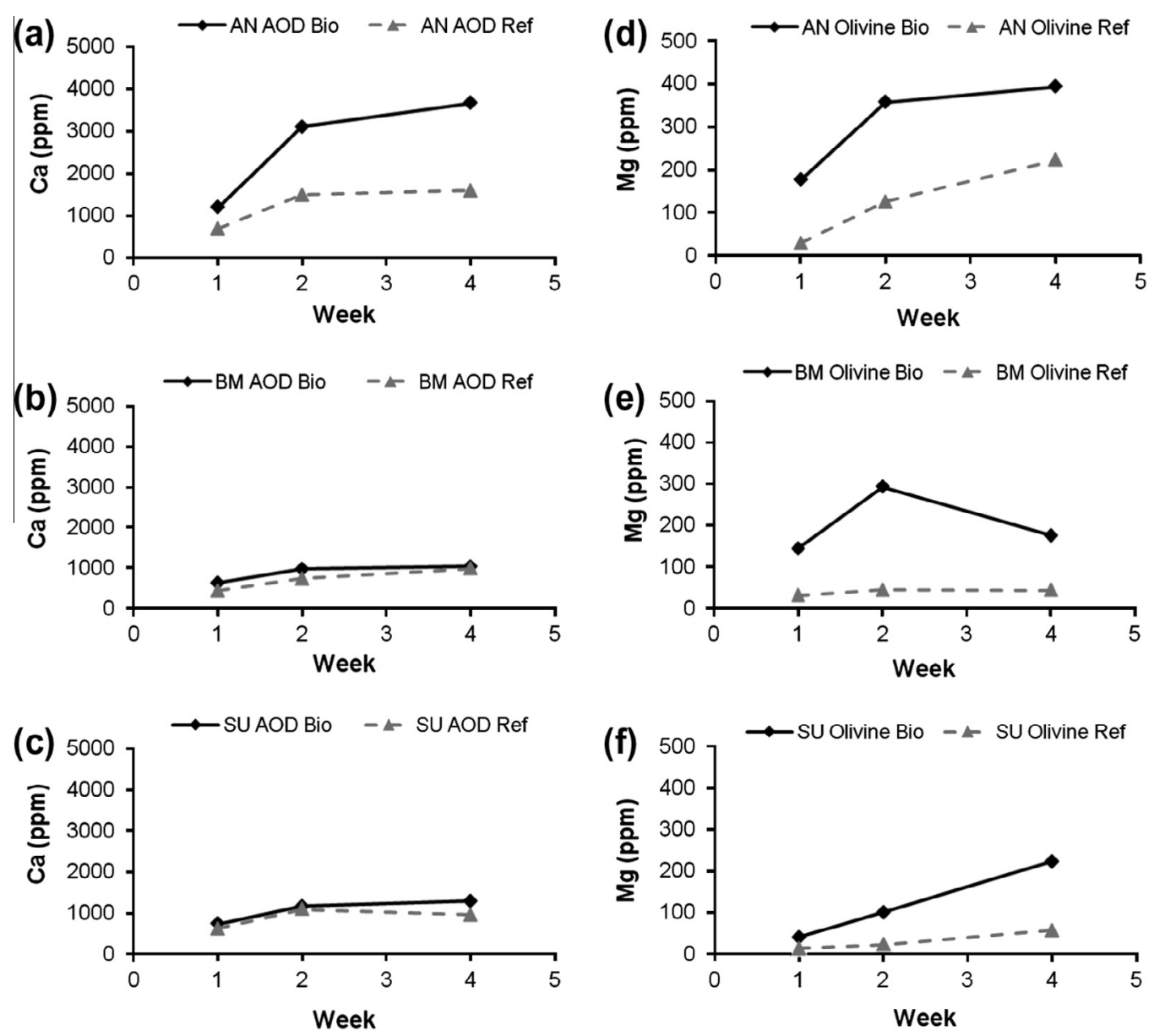

Fig. 4. Solubilised calcium (a, b, c) and magnesium (d, e, f,) concentrations from reference and bioleached (by AN, BM, and SU) AOD slag and olivine over time. 

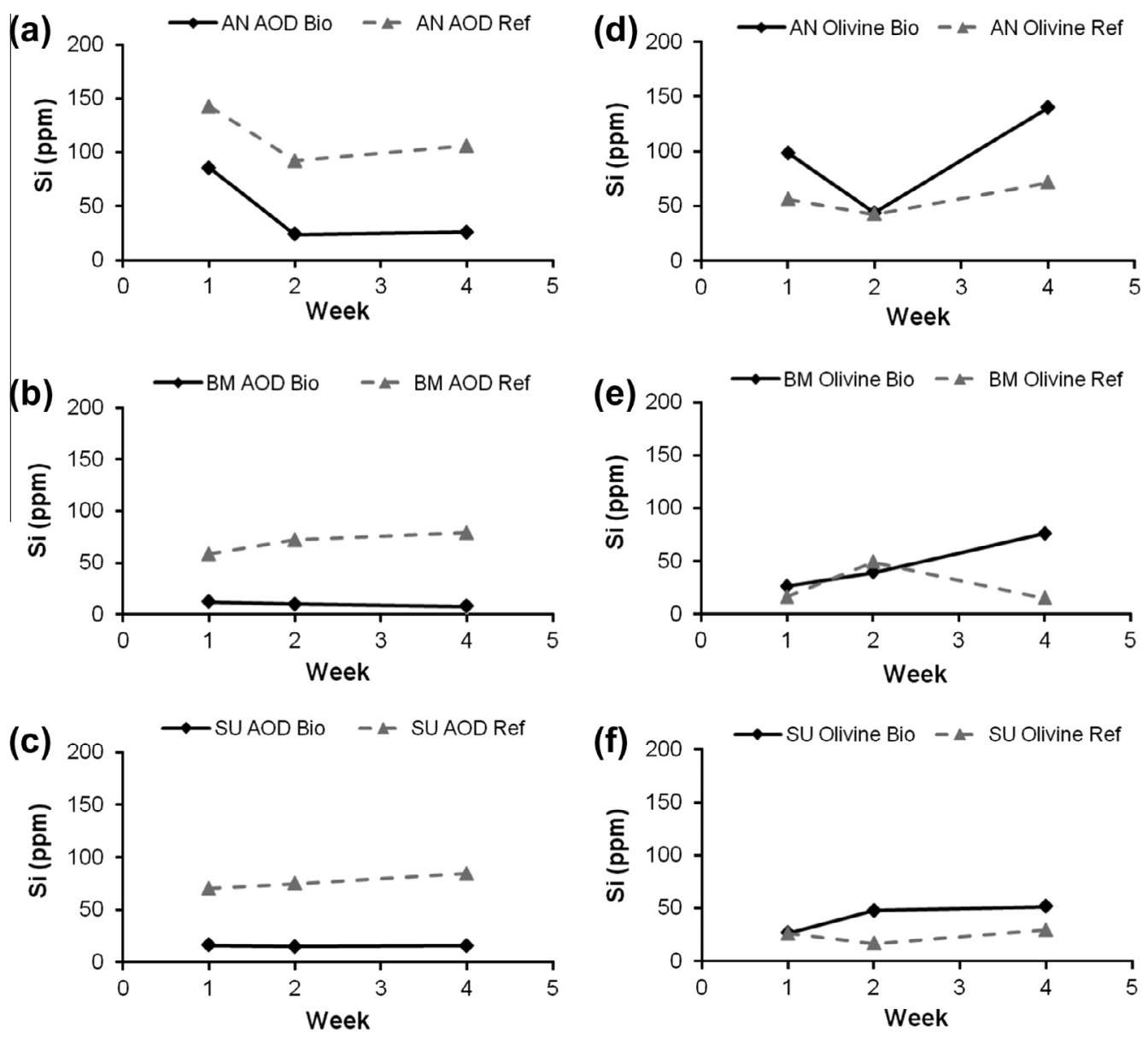

Fig. 5. Solubilised silica concentrations from reference and bioleached (by AN, BM and SU) AOD slag and olivine over time.

olivine dissolve stoichiometrically due to the orthosilicate nature of the mineral (Burkin, 2001); therefore biogenically induced reprecipitation of Si also appears to occur in this case.

Lastly, a positive effect on the leaching of nickel from olivine was observed. Fig. 6 presents the solubilisation trends of this metal. The nickel concentrations substantially increase compared to reference solutions (which have near zero values), with AN and SU solutions reaching values double that of BM. Olivine is known to be a nickel-bearing ore, however its relatively low nickel content (0.2-0.4 wt\% compared to $1-2.6 \mathrm{wt} \%$ of typical lateritic nickel ores (Brand et al., 1998)) and high alkalinity have made it economically unattractive for industrial hydrometallurgical processes (primarily

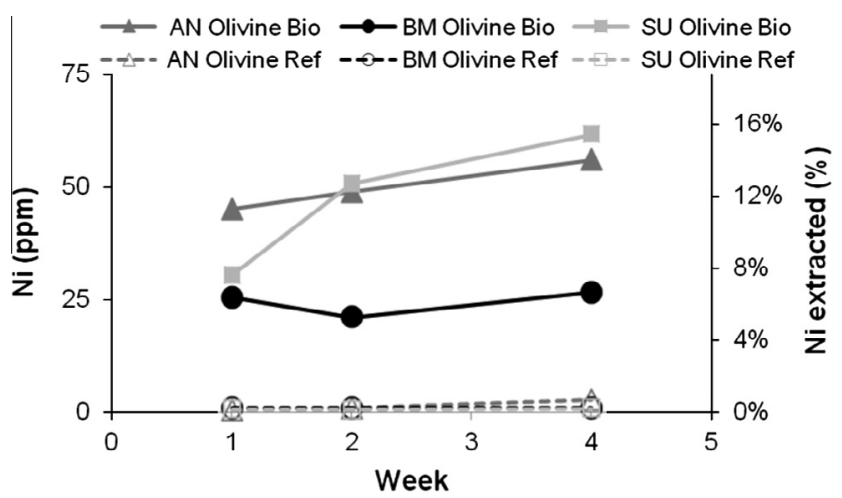

Fig. 6. Solubilised nickel concentrations and percentage extractions from reference and bioleached (by AN, BM and SU) olivine over time. based on high pressure acid leaching). Bioleaching may prove to be a feasible and sustainable solution for these lower grade ores, abundantly available on the Earth's crust (3\% of lithosphere (Ollier, 1984)). According to the nickel content of the olivine material utilised (0.4 wt\%), the leaching extents achieved in the present study represent up to $16 \%$ nickel extraction. Improvement of these values may require continuous rather than batch leaching (e.g. heap or column leaching) to overcome solubility limits, and reduction in solids particle size (here $200 \mu \mathrm{m}$ nominal size, considerably coarse compared to mineral processing standards).

\subsubsection{Solids analysis}

Bioleached solid materials were analysed by XRD to assess alteration of mineralogy and the creation or solubilisation of mineral phases. Analysis results of AOD diffractograms by Rietveld refinement are presented in Table 4. Shown are the main mineral phases that suffer significant alteration in content compared to reference samples (at least $1 \mathrm{wt} \%$ change ( $\Delta \mathrm{wt} \%)$, or $20 \%$ change of original content (\% change)). The content of gamma polymorph of dicalcium silicate $\left(\gamma-\mathrm{C} 2 \mathrm{~S}, \mathrm{Ca}_{2} \mathrm{SiO}_{4}\right)$ consistently decreases (by 5-13 wt\%) under the three bioleaching conditions. In contrast, the concentration of merwinite $\left(\mathrm{Ca}_{3} \mathrm{Mg}\left(\mathrm{SiO}_{4}\right)_{2}\right)$ consistently and significantly increases (by 5-15 wt\%) for all samples. These proportionally similar values may indicate a solubilisation-precipitation mechanism of mineral alteration. Fig. 7 displays the morphology of the bioleached solid particles; besides surface erosion, crystalline precipitation products can also be visualised, once compared to the rather uniform morphology of the original material (Fig. 1). Magnesium, present in merwinite, may originate from 
Table 4

Analysis of mineral alterations of bioleached (by AN, BM and SU) AOD slag determined by XRD and Rietveld refinement.

\begin{tabular}{|c|c|c|c|c|c|c|}
\hline \multirow[t]{2}{*}{ Mineral } & \multicolumn{2}{|c|}{ AN, AOD } & \multicolumn{2}{|c|}{$\mathrm{BM}, \mathrm{AOD}$} & \multicolumn{2}{|c|}{ SU, AOD } \\
\hline & $\Delta \mathrm{wt} \%$ & $\%$ Change & $\Delta \mathrm{wt} \%$ & $\%$ Change & $\Delta \mathrm{wt} \%$ & $\%$ Change \\
\hline$\gamma-\mathrm{C} 2 \mathrm{~S}, \mathrm{Ca}_{2} \mathrm{SiO}_{4}$ & -5.2 & -22 & -13.1 & -40 & -7.2 & -23 \\
\hline Periclase, MgO & -3.6 & -51 & ns & ns & +3.6 & +68 \\
\hline Bredigite, $\mathrm{Ca}_{14} \mathrm{Mg}_{2}\left(\mathrm{SiO}_{4}\right)_{8}$ & -8.5 & -50 & -1.7 & -9 & ns & ns \\
\hline Åkermanite, $\mathrm{Ca}_{2} \mathrm{MgSi}_{2} \mathrm{O}_{7}$ & ns & ns & -1.4 & -37 & -1.6 & -55 \\
\hline Merwinite, $\mathrm{Ca}_{3} \mathrm{Mg}\left(\mathrm{SiO}_{4}\right)_{2}$ & +11.1 & +98 & +14.7 & +166 & +5.0 & +71 \\
\hline Calcite, $\mathrm{CaCO}_{3}$ & +3.2 & +28 & +3.1 & +86 & ns & ns \\
\hline
\end{tabular}

ns $=$ Not significant (less than $1 \Delta \mathrm{wt} \%$ or $20 \%$ change).

the concurrent dissolution of bredigite $\left(\mathrm{Ca}_{14} \mathrm{Mg}_{2}\left(\mathrm{SiO}_{4}\right)_{8}\right)$ and åkermanite $\left(\mathrm{Ca}_{2} \mathrm{MgSi}_{2} \mathrm{O}_{7}\right)$ phases. It is unclear if changes in periclase $(\mathrm{MgO})$ can be attributed to $\mathrm{Mg}$ solubilisation (only moderate in the case of $\mathrm{AN}$, not shown previously), or if it is an artefact of the semi-quantitative analysis. The production of calcite $\left(\mathrm{CaCO}_{3}\right)$, however, appears to be better founded. Calcite likely is a product of the carbonation of degradation products of calcium silicates (i.e. $\mathrm{Ca}(\mathrm{OH})_{2}$, which was nearly absent ( $\left.<1 \mathrm{wt} \%\right)$ from all samples). The $\mathrm{CO}_{2}$ needed for this reaction may come from the atmosphere, or may very well come from the metabolic microbial activity, as a product of utilisation of organic energy sources (Hammes and Verstraete, 2002; Rendek et al., 2006). Calcite production from SU was negligible ( $0.3 \mathrm{wt} \%$ ), in line with the smaller mineral alterations produced with this bacteria, compared to the overall results of the other microorganisms.

XRD diffractograms of fresh and bioleached olivine samples are displayed in Fig. 8. The major mineral phases of olivine are forsterite $\left(\mathrm{Mg}_{2} \mathrm{SiO}_{4}\right)$ and forsterite ferroan $\left((\mathrm{Mg}, \mathrm{Fe})_{2} \mathrm{SiO}_{4}\right)$. The intensity of their peaks shifts moderately after bioleaching, potentially indicating morphological changes that alter preferential crystallographic directions. Fresh olivine also contains four identified silicates that are typically present in lateritic nickel ores (Brand et al., 1998), and which comprise approximately $8 \mathrm{wt} \%$ of the fresh sample: clinochlore $\left((\mathrm{Mg}, \mathrm{Fe})_{5} \mathrm{Al}\left(\mathrm{Si}_{3} \mathrm{Al}\right) \mathrm{O}_{10}(\mathrm{OH})_{8}\right)$, lizardite $\left(\mathrm{Mg}_{3} \mathrm{Si}_{2} \mathrm{O}_{5}(\mathrm{OH})_{4}\right)$, nimite $\left((\mathrm{Ni}, \mathrm{Mg}, \mathrm{Fe})_{5} \mathrm{Al}\left(\mathrm{Si}_{3} \mathrm{Al}\right) \mathrm{O}_{10}(\mathrm{OH})_{8}\right)$, and willemseite $\left((\mathrm{Ni}, \mathrm{Mg})_{3} \mathrm{Si}_{4} \mathrm{O}_{10}(\mathrm{OH})_{2}\right)$. The main peaks of these minerals are marked for fresh olivine in Fig. 8. These phases disappear nearly completely after bioleaching; the content of these minerals in the three bioleached samples reduces to below $3 \mathrm{wt} \%$ as determined by quantitative XRD. This is in agreement with nickel solubilisation observed (presented in Section 3.3.1).

Mineral degradation is also evident by the change in material specific surface area measured by nitrogen adsorption. BET isotherms of fresh and bioleached AOD slag and olivine are shown in Fig. 9 along with $S_{\mathrm{BET}}$ values. For both materials there is a substantial increase in surface area, with bioleached AOD slag having the greatest change. The increased surface area is predominantly due to the generation of micropores (evidenced by the sharp adsorption increase at low relative pressure $\left(P / P_{\mathrm{o}}<0.01\right)$ ) (Tan et al., 2007), which may be mainly related to precipitation of altered minerals from solubilised components. AN produced the greatest increase in surface area for AOD slag, while BM delivered slightly superior results for olivine. The hysteresis loops occurring in the pressure range $0.45<P / P_{\mathrm{o}}<1.0$ are due to the formation of the macropores (Tan et al., 2007), indicating bioleaching induced degradation of particle surfaces, creating cracks and crevices. Increased specific surface areas and porosity are encouraging results, as these factors can potentially improve the sorption capacity and reactivity (towards mineral carbonation or chemical leaching, for example) of certain materials.

In order to characterise the residual biomass on the recuperated dried solids, TGA and FTIR analyses were performed. Fig. 10 shows the thermogravimetrical data of fresh and bioleached samples of AOD slag and olivine. The mass drop in the range of $200-400{ }^{\circ} \mathrm{C}$
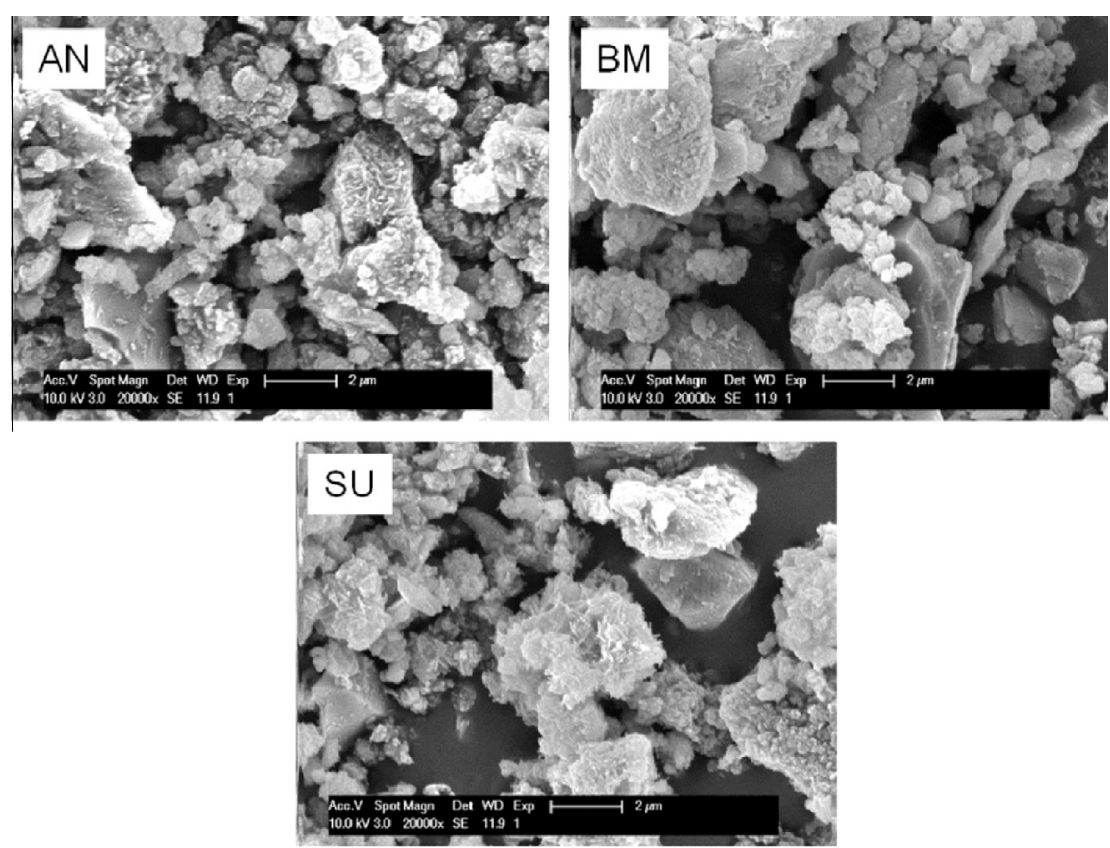

Fig. 7. Morphology of bioleached (by AN, BM and SU) AOD inspected by SEM $(20,000 \times$ magnification). 


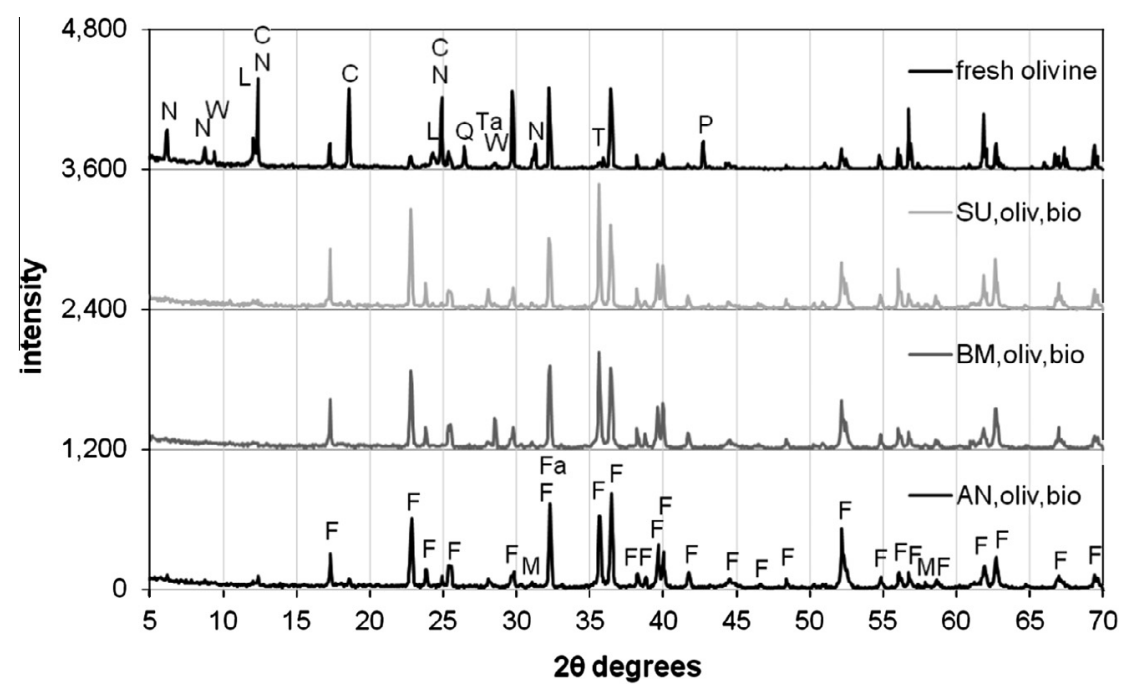

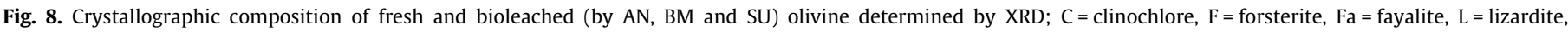
$\mathrm{M}=$ magnetite, $\mathrm{N}=$ nimite, $\mathrm{P}=$ periclase, $\mathrm{Q}=$ quart $\mathrm{T}, \mathrm{T}=$ tirodite, $\mathrm{Ta}=$ talc, $\mathrm{W}=$ willemseite.
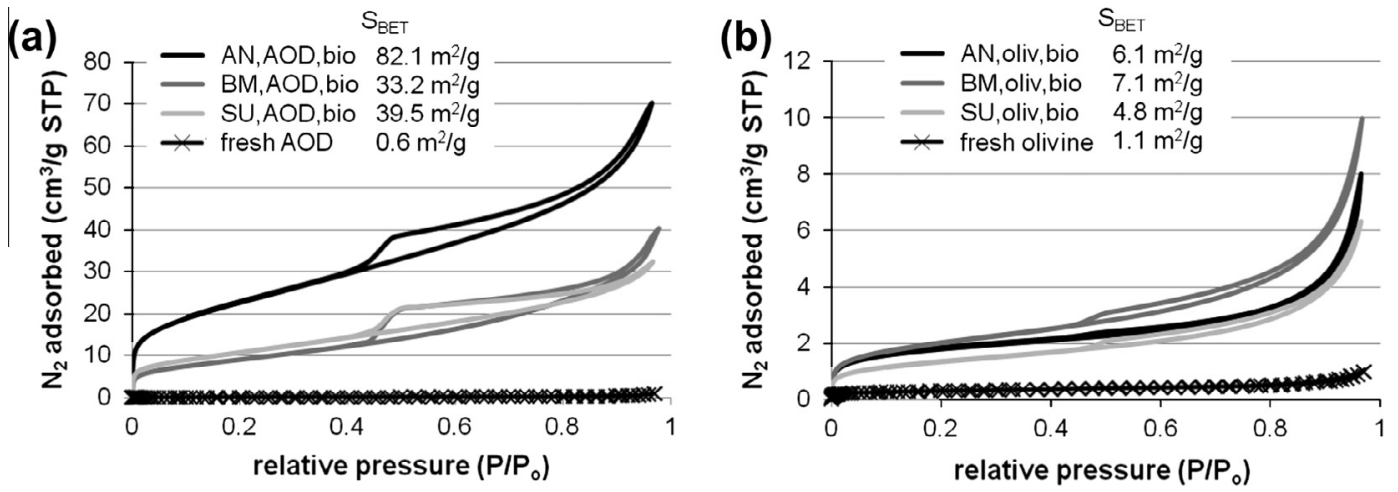

Fig. 9. Nitrogen adsorption isotherms of fresh and bioleached (by AN, BM and SU) AOD slag (a) and olivine (b).

can be predominantly attributed to decomposition of EPS materials (Ismail and Nampoothiri, 2010; Wang et al., 2010); it is noted that the drop is more significant for AOD slag than for olivine, and for AN than for the other microorganisms. This is in line with the previously proposed mechanism for reduction of Si leaching in the case of AOD slag, due to attachment of Si to insoluble biogenic materials. Further heating of the samples induces the decomposition of carbonates (up to $800^{\circ} \mathrm{C}$ ).

FTIR also suggests greater EPS content on AOD slag than on olivine (Fig. 11). The intense broad stretching peaks around $3,307 \mathrm{~cm}^{-1}$, which can be attributed to hydroxyl groups, are char- acteristic of polysaccharides, while the strong absorption at $1,652 \mathrm{~cm}^{-1}$ and $1,448 \mathrm{~cm}^{-1}$ can be related to biogenic proteins and peptides (Wang et al., 2010). Remaining peaks below $1,000 \mathrm{~cm}^{-1}$ are inherent of the silicate materials.

\section{Conclusions}

The results presented here suggest that alkaline bioleaching can be a potentially valuable process for the treatment of alkaline materials prior to valorisation (e.g. as carbon sinks or as sorbents) or for utilization of these abundant materials as metal ores (e.g.
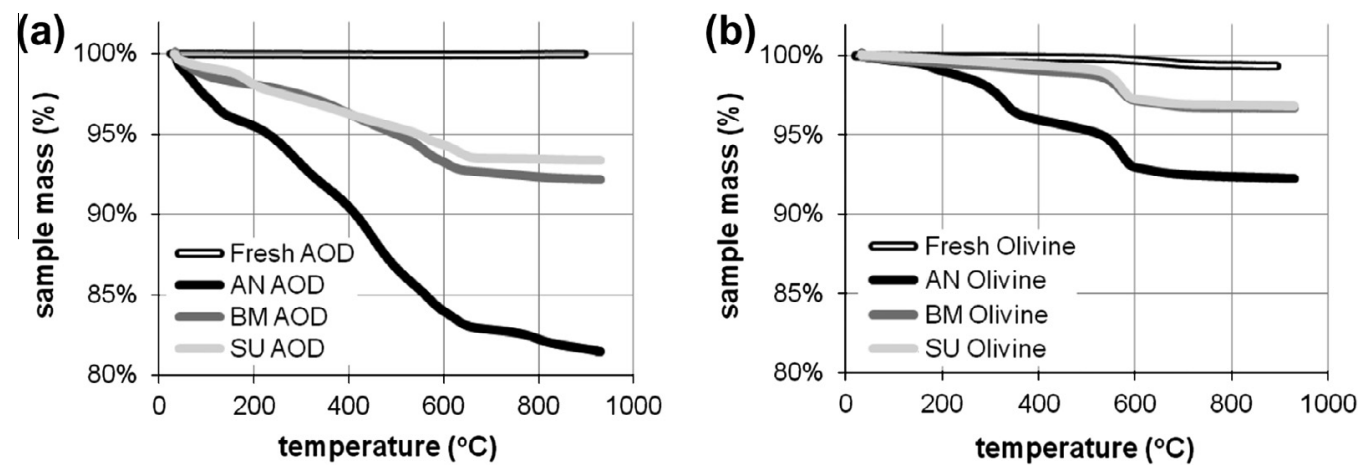

Fig. 10. Loss on ignition (LOI) of fresh and bioleached (by AN, BM and SU) AOD slag (a) and olivine (b) determined by TGA. 


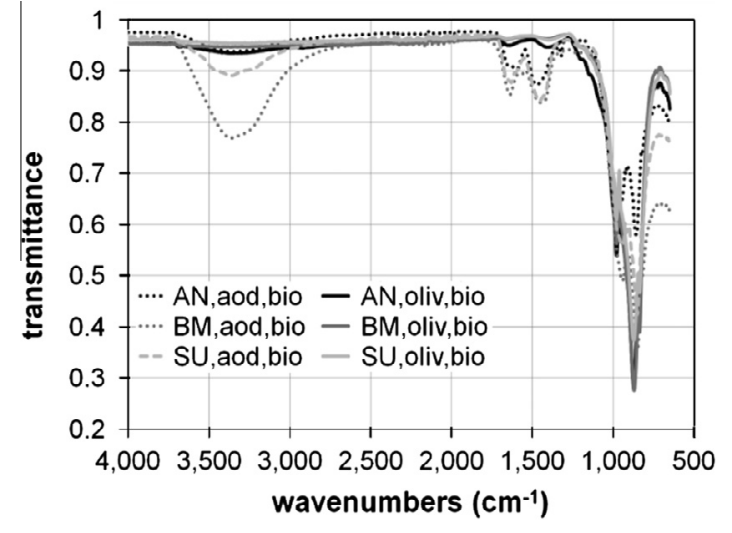

Fig. 11. FTIR spectrum of bioleached (by AN, BM and SU) AOD slag and olivine.

nickel from olivine). Bioleaching induced positive results with respect to increased solubilisation of alkaline earth metals and nickel, and the alteration of basicity, mineralogy and morphology of solid materials. The similarities between fungal and bacterial mediated bioleaching suggest that biogenic substances such as organic acids and exopolysaccharides contribute mostly to these effects, as opposed to bioaccumulation or other direct action of living cells. This aspect supports the use of two-step bioleaching as opposed to one-step, since the biogenic substances can be produced under optimal conditions prior to the introduction of potentially hazardous solid materials. Further work is required to better understand the bioleaching mechanisms. Routes for optimisation of the biochemical processes include: (i) adoption of continuous leaching (e.g. heap or column) to overcome solubility limits; (ii) genetic amelioration of the utilised microorganisms, to produce strains more resistant to alkaline environments and to the presence of heavy metals, and that generate greater quantities of the key lixiviant biogenic substances; and (iii) identification of other suitable strains isolated from alkaline environments (e.g. mining and metallurgical waste sites and biodeteriorated cementitious and stony structures).

\section{Acknowledgements}

The K.U. Leuven Industrial Research Fund (IOF) is gratefully acknowledged for funding the Knowledge Platform on Sustainable Materialization of Residues from Thermal Processes into Products $\left(\right.$ SMaRT-Pro $^{2}$ ) in which this work was performed. R.M.S. is thankful for the PGS-D support from the Natural Sciences and Engineering Research Council of Canada (NSERC). The K.U. Leuven Department of Earth and Environmental Sciences and the Department of Metallurgy and Materials Engineering are acknowledged for the use of XRD, LD, and SEM equipment. Special thanks to the 2012 final year chemistry class of the KHBO for assistance in the preliminary screening experiments.

\section{References}

Amiri, F., Yaghmaei, S., Mousavi, S.M., Sheibani, S., 2011. Recovery of metals from spent refinery hydrocracking catalyst using adapted Aspergillus niger. Hydrometallurgy 109, 65-71.

Ball, D., Banik, A.K., 2011. Role of macro and micro elements on bioleaching of silica from Indian chromite ore by Aspergillus niger AB200. Journal of the Indian Chemical Society 88 (9), 1355-1359.

Ball, D., Barman, S.G., Banik, A.K., 2010. Studies on bioleaching of silica from Indian chromite ore by a silica tolerant Aspergillus niger $\mathrm{AB}(200)$ : characterisation of some physical parameters and scanning electron microscopic studies. Journal of the Indian Chemical Society 87 (7), 857-862.
Bansal, V., Syed, A., Bhargava, S.K., Ahmad, A., Sastry, M., 2007. Zirconia enrichment in zircon sand by selective fungus-mediated bioleaching of silica. Langmuir 23 4993-4998.

Brand, N.W., Butt, C.R.M., Elias, M., 1998. Nickel laterites: classification and features. AGSO Journal of Australian Geology \& Geophysics 17 (4), 81-88.

Burkin, A.R., 2001. Chemical Hydrometallurgy: Theory and Principles. Imperial College Press, London.

Chandraprabha, M.N., Natarajan, K.A., 2010. Microbially induced mineral beneficiation. Mineral Processing and Extractive Metallurgy Review 31, 1-29.

Chiang, Y.W., Karel Ghyselbrecht, K., Santos, R.M., Meesschaert, B., Martens, J.A., 2012. Synthesis of zeolitic-type adsorbent material from municipal solid waste incinerator bottom ash and its application in heavy metal adsorption. Catalysis Today 190 (1), 23-30.

De Belie, N., 2010. Microorganisms versus stony materials: a love-hate relationship. Materials and Structures 43, 1191-1202.

De Windt, L., Devillers, P., 2010. Modeling the degradation of Portland cement pastes by biogenic organic acids. Cement and Concrete Research 40, 11651174.

Groudeva, V., Krumova, K., Groudev, S., 2007. Bioleaching of a rich-in-carbonates copper ore at alkaline $\mathrm{pH}$. Advanced Materials Research 20-21, 103-106.

Hammes, F., Verstraete, W., 2002. Key roles of $\mathrm{pH}$ and calcium metabolism in microbial carbonate precipitation. Reviews in Environmental Science and Biotechnology 1, 3-7.

Ismail, B., Nampoothiri, K.M., 2010. Production, purification and structural characterization of an exopolysaccharide produced by a probiotic Lactobacillus plantarum MTCC 9510. Archives of Microbiology 192, 1049-1057.

Kulkarni, S., Syed, A., Singh, S., Gaikwad, A., Patil, K., Vijayamohanan, K., Ahmad, A., Ogale, S., 2008. Silicate nanoparticles by bioleaching of glass and modification of the glass surface. Journal of Non-Crystalline Solids 354, 3433-3437.

Kuwahara, Y., Ohmichi, T., Kamegawa, T., Mori, K., Yamashita, H., 2010. A novel conversion process for waste slag: synthesis of a hydrotalcite-like compound and zeolite from blast furnace slag and evaluation of adsorption capacities. Journal of Materials Chemistry 20, 5052-5062.

Liu, W., Xu, X., Wu, X., Yang, Q., Luo, Y., Christie, P., 2006. Decomposition of silicate minerals by Bacillus mucilaginosus in liquid culture. Environmental Geochemistry and Health 28, 133-140.

Mohanty, B.K., Ghosh, S., Mishra, A.K., 1990. The role of silica in Bacillus lichenifomis. Journal of Applied Bacteriology 68, 55-60.

Mulligan, C.N., Kamali, M., 2003. Bioleaching of copper and other metals from lowgrade oxidized mining ores by Aspergillus niger. Journal of Chemical Technology and Biotechnology 78, 497-503.

Ollier, C., 1984. Weathering, second ed. Longman, London.

Power, I.M., Dipple, G.M., Southam, G., 2010. Bioleaching of ultramafic tailings by acidithiobacillus spp. for $\mathrm{CO}_{2}$ sequestration. Environmental Science \& Technology 44, 456-462.

Rendek, E., Ducom, G., Germain, P., 2006. Influence of organic matter on municipal solid waste incinerator bottom ash carbonation. Chemosphere 64, 1212-1218.

Santos, R.M., Van Gerven, T., 2011. Process intensification routes for mineral carbonation. Greenhouse Gases: Science and Technology 1 (4), 287-293.

Tan, Q., Bao, X., Song, T., Fan, Y., Shi, G., Shen, B., Liu, C., Gao, X., 2007. Synthesis, characterization, and catalytic properties of hydrothermally stable macromeso-micro-porous composite materials synthesized via in situ assembly of preformed zeolite Y nanoclusters on kaolin. Journal of Catalysis 251, 69-79.

Vandevivere, P., Welch, S.A., Ullman, W.J., Kirchman, D.L., 1994. Enhanced dissolution of silicate minerals by bacteria at near-neutral $\mathrm{pH}$. Microbial Ecology 27, 241-251.

Vrvić, M.M., Matić, V., Vučetić, J., Vitorović, D., 1990. Demineralization of an oil shale by Bacillus circulans ("siliceous bacteria"). Organic Geochemistry 16 (4-6), 1203-1209.

Wang, D., Cullimore, R., Hu, Y., Chowdhury, R., 2011. Biodeterioration of asbestos cement $(\mathrm{AC})$ pipe in drinking water distribution systems. International Biodeterioration \& Biodegradation 65, 810-817.

Wang, Y., Li, C., Liu, P., Ahmed, Z., Xiao, P., Bai, X., 2010. Physical characterization of exopolysaccharide produced by lactobacillus plantarum KF5 isolated from Tibet Kefir. Carbohydrate Polymers 82, 895-903.

Warscheid, Th., Braams, J., 2000. Biodeterioration of stone: a review. International Biodeterioration \& Biodegradation 46, 343-368.

Welch, S.A., Barker, W.W., Banfield, J.F., 1999. Microbial extracellular polysaccharides and plagioclase dissolution. Geochimica et Cosmochimica Acta 63 (9), 1405-1419.

Wiktor, V., Grosseau, P., Guyonnet, R., Garcia-Diaz, E., Lors, C., 2011. Accelerated weathering of cementitious matrix for the development of an accelerated laboratory test of biodeterioration. Materials and Structures 44, 623-640.

Willscher, S., Bosecker, K., 2003. Studies on the leaching behaviour of heterotrophic microorganisms isolated from an alkaline slag dump. Hydrometallurgy 71, 257264.

Wu, H.-Y., Ting, Y.-P., 2006. Metal extraction from municipal solid waste (MSW) incinerator fly ash-Chemical leaching and fungal bioleaching. Enzyme and Microbial Technology 38, 839-847.

Yang, J., Wang, Q., Wang, Q., Wu, T., 2008. Comparisons of one-step and two-step bioleaching for heavy metals removed from municipal solid waste incineration fly ash. Environmental Engineering Science 25 (5), 783-789.

Yang, J., Wang, Q.-H., Luo, Q.-S., Wang, Q., Wu, T.-J., 2010. Effect of desilication treatment using silicate bacteria on the bioleaching efficiency of municipal solid waste incineration fly ash. Environmental Science 31 (1), 266-272. 